\title{
Uvodna riječ
}

Knjiga koju predajemo u ruke čitatelja rezultat je međunarodnoga umjetničko-znanstvenog skupa pod naslovom Od mobilnosti do interakcije. (Re)vizije dramskog pisma i kazališta u Jugoslaviji i nove dramsko-kazališne produkcije u Bosni i Hercegovini, Crnoj Gori, Hrvatskoj, na Kosovu, u Makedoniji, Sloveniji i Srbiji koji je organizirao Zavod za teoriju književnosti i traduktologiju Instituta za slavensku filologiju Filološkog fakulteta Šleskog sveučilišta u Katowicama. Skup je dio većeg trogodišnjeg projekta pod naslovom (Trans)pozicije ideja u hrvatskom i srpskom dramskom pismu i kazalištu (1990.-2020.). Transkulturna perspektiva koji realizira na Šleskom sveučilištu dr. Gabriela Abrasowicz i koji financira u okviru projekta Sonatina 1 Poljski nacionalni centar za znanost. Skup se održao od 7. do 9. studenoga u Sosnowiecu i u Katowicama. Sudjelovalo je u njemu dvadeset osam sudionika: četiri s poljskih sveučilišta: Jagelonskog sveučilišta u Krakovu, Sveučilišta Adama Mickiewicza u Poznanju te predstavnici domaćina Šleskog sveučilišta u Katowicama i dvadeset četiri sudionika iz inozemstva (predstavnici Sveučilišta u Zagrebu, Sveučilišta u Zadru, Sveučilišta u Osijeku, Sveučilišta u Skopju, Univerziteta u Crnoj Gori, Univerziteta umetnosti u Beogradu, Univerziteta Singidunum u Beogradu te različitih kulturnih ustanova i slobodni umjetnici). Skup je bio organiziran u suradnji sa Šleskim muzejom te Institucijom za kulturu grada Katowice Ars Cameralis Silesiae Superioris koja je sufinancirala dolazak i boravak troje suvremenih dramskih pisaca: Tanje Šljivar, Milene Bogavac i Gorana Ferčeca. U skupu su sudjelovali istaknuti komparatisti, slavisti, teatrolozi, kazališni ljudi.

Popodne prvog dana skupa sudionici su pozvani u Teatar Zagłębia u Sosnowiecu koji zauzima značajno mjesto u povijesti hrvatsko-poljskih kazališnih veza kao pozornica na kojoj je održana 1958., među ostalim, poljska praizvedba Držićeva Dunda Maroja. Istog su dana sudionici skupa također posjetili novu zgradu Šleskog muzeja u kojem se nalazi Centar poljske scenografije. Muzej je izgrađen na mjestu bivšeg rudnika Katowice čiji je teren revitaliziran i pretvoren danas $u$ zonu kulture $u$ kojoj 
se osim muzeja nalazi sjedište i koncertna dvorana Nacionalnog simfonijskog orkestra Poljskog radija. Drugog dana u Teatru bez scene održala se predstava - monokoreodrama u izvedbi Selme Mehić pod naslovom $\mathrm{Kr}$ ležina Saloma. Rekvijem za mladog umjetnika (detalji su tog projekta predstavljeni u jednom od tiskanih radova). Umjetnički je dio skupa zatvorio susret Balkanski mostovi organiziran 10. studenoga u Šleskom kazalištu u okviru 27. Festivala Ars Cameralis. Razgovor s piscima vodila je dr. Gabriela Abrasowicz. Pratilo ga je scensko čitanje ulomaka tekstova Milene Bogavac, Gorana Ferčeca i Tanje Šljivar. Na kraju se održao koncert Danijela Kovača i njegova ansambla Jesenji orkestar.

Autori su se u svojim izlaganjima, među ostalim, bavili kulturnom mobilnošću u drami i kazalištu, pitanjima kulturnog transfera, lokalnošću, globalizacijskim procesima, transgresijom, (de)konstrukcijom hibridnog identiteta, transkulturalnošću i translacijom. Skup je bio jedinstvena inicijativa ove vrste od trenutka raspada druge Jugoslavije. Kao što su naglašavali sudionici konferencije, koji su došli iz Bosne i Hercegovine, Hrvatske, Crne Gore i Srbije, skup je bio prvi takav susret „na neutralnom terenu”, zahvaljujući kojem se moglo zajednički diskutirati i predstavljati svoje sredine i projekte. Od dvadeset osam izlaganja objavljujemo sedamnaest poslanih izlaganja. Osamnaesti rad je rad jednog od sudionika koji nije mogao doći u Poljsku.

Među autorima našle su se osobe iz različitih sredina, s različitim iskustvom i u različitoj fazi vlastitog profesionalnog djelovanja. Od svih radova možemo izdvojiti nekoliko tematskih odnosno problemskih ciklusa. Prvi Pogled unatrag - čine članci Magdalene Koch, Ninoslave Vićentić i Snježane Banović koji govore o prošlosti, naime prvi o dramskom opusu Laure Papo, sefardske dramaturginje iz Sarajeva, drugi o ulozi ruskih umjetnika u razvoju srpske scenografije te treći o kratkoj epizodi socrealizma u hrvatskom kazalištu. Drugi - Drama i kazalište u društvu - čine članci koji su pokušaji svojevrsne sinteze hrvatske dramske i kazališne produkcije u drugoj polovici 20. stoljeća (Sanja Nikčević, Helena Peričić) te suvremene srpske drame nakon 1995. godine (Miroslav Radonjić). Treći - Prijevodna i izvedbena mobilnost - sastoji se od radova, da se poslužim terminom koji je upotrijebila u svom članku Lada Čale Feldman, o prijevodnoj i izvedbenoj mobilnosti, naime, o engleskoj recepciji drame Tene Štivičić pod naslovom Tri zime / Three winters (Lada Čale Feldman), o prijevodima hrvatske drame na strane jezike (Martina Petranović), o stranoj recepciji dramskog opusa Mire Gavrana (Lucija Ljubić), o francuskom festivalu Croatie, la voici (Anera Stopfer) ta na kraju o radu nacionalnoga Centra ITI na promociji hrvatskih drama i dramatičara u svijetu (Željka Turčinović). Četvrti - Tumačenja drama - čine radovi koji dublje ulaze $u$ interpretaciju pojedinih drama i/ili predstava, a to su rad troje autora - Une Bauer, Agate Juniku i Gorana Pavlića koji vode trijalog o trima predstavama - Govori glasnije Bobe Jelčića, Ciganin, ali najljepši 
Ivice Buljana i Ljudski glas Bojana Đorđeva te članak Ivane Žužul koji iz perspektive naratoloških studija nudi tumačenje Zajčeve drame John Smith, Princeza od Walesa. Zatim Maja Đurinović, u već najavljenom tekstu, opisuje nastajanje scenske interpretacije, dakle intersemiotičkog prijevoda Krležine Salome. Na kraju tog ciklusa dramska spisateljica Tanja Sljivar opisuje autoričino autoreferencijalno čitanje predstave Rose is a rose is a rose is a rose Ivane Sajko. Posljednji se ciklus - Mobilnost umjetnosti - sastoji od dvaju članaka: dvoje autora Sibile Petlevski i Davida Gazarova u kojem se govori, među ostalim, o virtualnoj mobilnosti umjetnika te članak suurednice Gabriele Abrasowicz, koja je istodobno autorica teme i poziva na skup. Njezin opis dramskog stvaralaštva i produkcije ostao je jedinstven u cijelom zborniku jer nijedan od drugih autora nije usvojio takvu perspektivu opisa sličnih, supostojećih, sinkronijskih pojava $u$ „dramskoj i pozorišnoj produkciji u postjugoslovenskom regionu".

Zahvaljujemo svima koji su sudjelovali u projektu. Posebno zahvaljujemo sudionicima skupa i recenzentici zbornika profesorici Magdaleni Bogusławskoj koja je svojim komentarima i primjedbama pomogla svima nama dati završni oblik ovome projektu. Nadamo se da će ubuduće mobilnost i nadalje pridonositi razumijevanju ne samo Drugog, nego kroz otkrivanje Drugog razumijevanju sebe.

Leszek Małczak

(D) https://orcid.org/0000-0002-0665-3606 https://doi.org/10.31261/PN.3977.01 